\title{
Evolution of Acrylamide Detection Methods in Cooked Foods since its firstly Discovered in 2002 \\ Review Article
}

Nada Ibrahim Hussein Ahmed A. M., and*Ingolf U. Gruen

Dept. of Food Hygiene, Faculty of Veterinary Medicine, Suez Canal

University, Egypt,

*Food science Dept. University of Missouri, USA

\begin{abstract}
The changing of contemporary life with fast style consequently its need for fast ready meals given raise chemical food safety hazards from thermally processed one. Acrylamide, neurotoxin and DNA damage, has been found in different thermally processed foods such as potato chips, biscuits, and bread. Limit literature was done upon its existence in fried meat and/or fish. This paper provides a comprehensive overview of detection of Acrylamide in different foods since the first discovered in April 2002, in fried food by researchers from the Swedish National Food Administration and the University of Stockholm unite. Recent methods based on the nanotechnology as well as molecular biology are presented. The review shows high sensitivity, selectivity, stability, and repeatability methods as liquid chromatography coupled with tandem mass spectrometry. Also, rapid detection methods with merits of simplicity and portability such as computer vision, ELISA, electrochemical biosensing, and fluorescent biosensing. Some methods are expensive although recent methods seem to be cheaper. Meanwhile, suggestions for further research on rapid methods for detecting Acrylamide are also discussed based on types of foods and technical challenges.
\end{abstract}

\section{Introduction}

Acrylamide, (2-propenamide, C3H5NO (71.09 gmol_1, CASNo. 79-06-1)) a well-known human neurotoxic chemical toxin, was detected in fried or baked food.

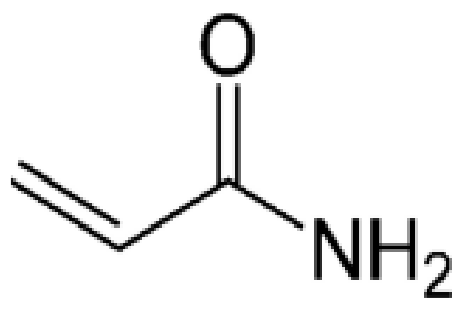

Acrylamide $\left(\mathrm{CH}_{2}=\mathrm{CHCONH}_{2}\right)$ 
Acrylamide (AA) is a lowmolecular weight vinylic compound. It is a colorless and odorless crystalline substance and it is highly water soluble, easily reactive in air, and rapidly polymerizable. Thermal food processing especially meat and their products can have some accidental changes as the destruction of amino acids and the synthesis of hazards chemicals as heterocyclic amines, acrolein, furan, and acrylamide. Generally, all cooking methods likely to produce acrylamide in foods except boiling (figure 1). The early study by Yasuhara et al. (2003) suggested that in the thermal processing of lipid-rich food as meat may also play an important role in acrylamide formation. In spite of the fact that high carbohydrate foods have been widely measured for the estimation of AA, preparing high protein foods like meat at high temperature can also be a reason of generating AA, reaching levels up to $300 \mathrm{mg} / \mathrm{kg}$ (Kaplan et al., 2009; DelgadoAndrade, et al., 2010 and Demirok \& Kolsarici, 2014).

AA is a Maillard reaction product, which forms instinctively as frying or cooking heat treatment imposed in foods (Claus et al., 2008). One of the major MRP is acrylamide which is developed mostly from free asparagine and reducing sugar throughout cooking foods at high temperatures (above $120^{\circ} \mathrm{C}$ ). A nearly recent study done by Trevisan et al. (2016) confirmed temperature as an important factor for the production of acrylamide in grilled meat. They grilled and fried hamburgers to an internal temperature below $90^{\circ} \mathrm{C}$ and found that furosine was formed, When the temperature reached $90^{\circ} \mathrm{C}$ and $100^{\circ} \mathrm{C}$, furosine content decreased by $36 \%$ and fluorescent compounds increased by up to $98 \%$. Baking meat at $300^{\circ} \mathrm{C}$, the most severe heat treatment studied, resulted in the formation of carboxymethyllysine.

According to Food and Agriculture Organization of the United Nations and World Health Organization (FAO/WHO), daily intake of the AA from the food can be in the range of $0.3-\quad 0.8 \quad \mu \mathrm{g} / \mathrm{kg}$ (FAO/WHO, 2002). The daily intake of the AA from food 1-10 $\mathrm{mg} / \mathrm{kg}$ ) higher than this value can cause toxic effects on humans.

Acrylamide has been proved to cause genotoxicity, muscle weakness, neurotoxicity, sensory loss, and carcinogenicity. Indeed, acrylamide exhibits potential to alky-late nucleophilic center in DNA molecule and initiates mutations and alternations in gene expression in human cells (Oracz, et al., 2011). Therefore, this article through the light on the common methods for detection AA as hazards chemical toxin and their ability to application in fried meat. 


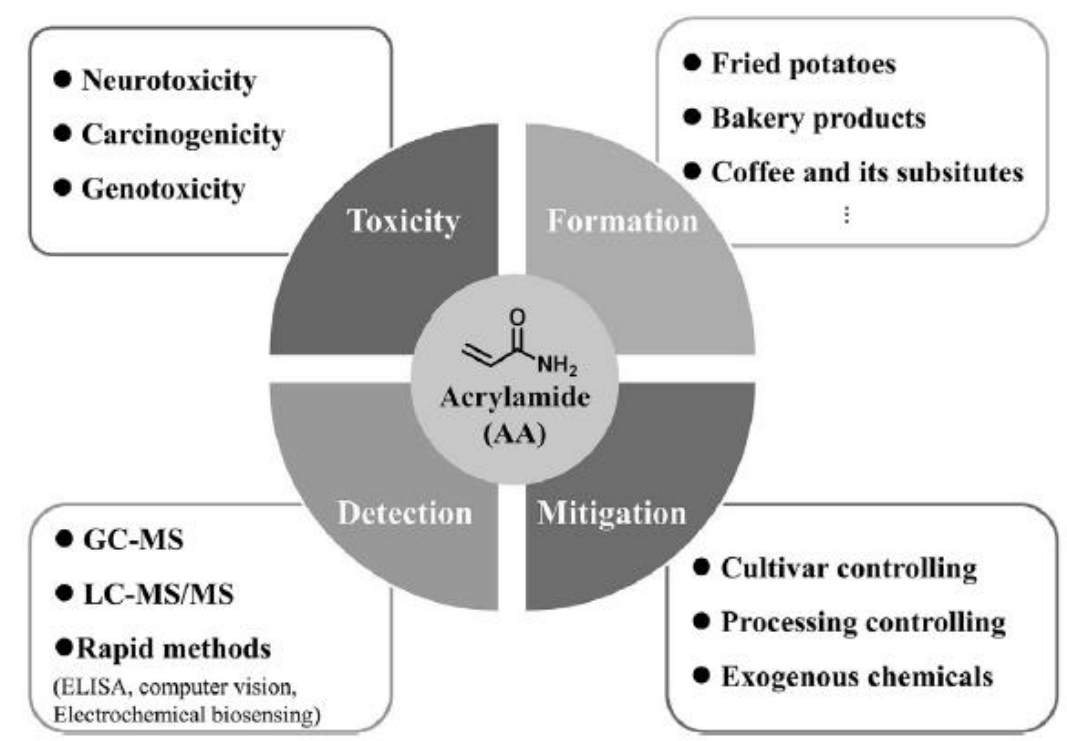

Figure 1: Recent researches on acrylamide in thermally processed food by Hu et al., (2015)

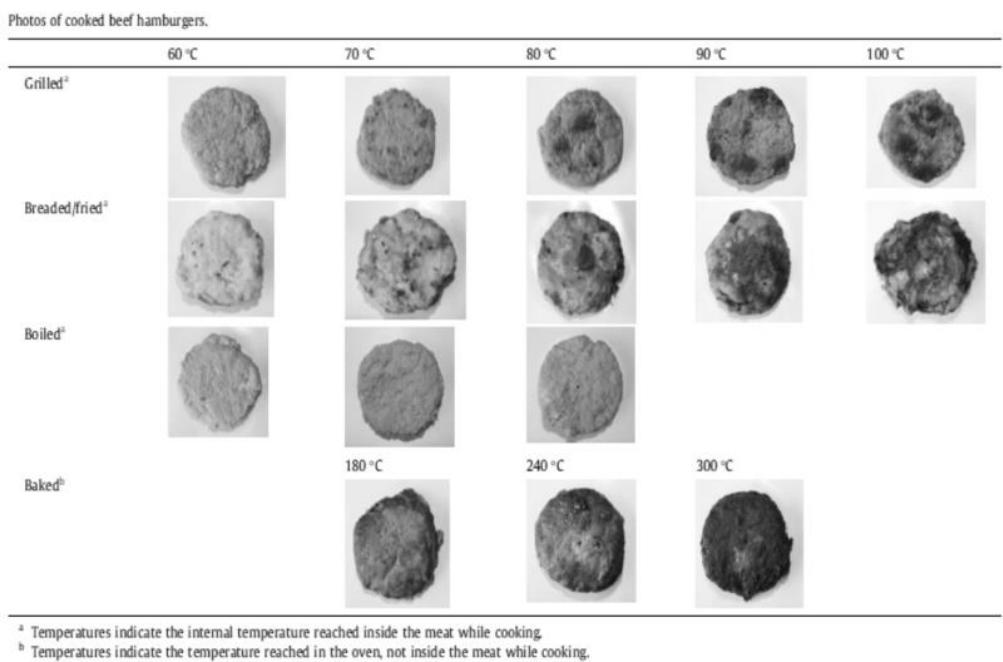

Figure 2. Trial of Trevisan et al. (2016) for study the effect of temperature changes on acryalmide formation in beef burger 
Table 1. Measured levels of acrylamide in meat according to Eriksson (2005)

\begin{tabular}{l} 
Type of food \\
(Number of samples/analysis) \\
\hline Laboratory-fried protein-rich food \\
Beef, minced (5) \\
Chicken, minced (2) \\
Cod, minced (3)
\end{tabular}

Methods of detection of AA

In April 2002, the formation of acrylamide in starch-rich foods or high-temperature cooking, like with a variety of baked and fried foods cooked at high temperature, was reported by researchers from the Swedish National Food Administration (SNFA) and the University of Stockholm (Keramat et al., 2010). At that time, there was no sufficiently validated method for the detection of acrylamide.

\section{Conventional detection} methods

Liquid Chromatography-Mass Spectrophotometer (LC-MS/MSbased) method (figure 2) was then developed by various investigators as Rosén andHellenäs (2002); Ono et al. (2003); Swiss Federal Office of PublicHealth (2002); Takatsuki
Acrylamide content;

median (range)

( $\mu \mathrm{g} / \mathrm{kg}$ heated food)

$$
\begin{aligned}
& 17(15-22) \\
& 28(16-41) \\
& <5(<5-11)
\end{aligned}
$$

et al. (2003); US Food and Drug Administration (2003).

The main techniques for analyzing AA in food samples are liquid and gas chromatography, both coupled with mass spectrometry (LC- and GC-MS) after extraction (with water or mixtures of water and organic solvents) and clean-up of the food extract (mainly by Solid Phase Extraction (SPE), or by matrix solid-phase dispersion methods (MSPD) or solid phase microextraction (SPME) (EFSA, 2015).

So far, many analytical methods have been used to quantify acrylamide in food products. Most of them are expensive and demand sophisticated instruments, such as high-performance liquid chromatography (HPLC) (Qin et al., 2017). 


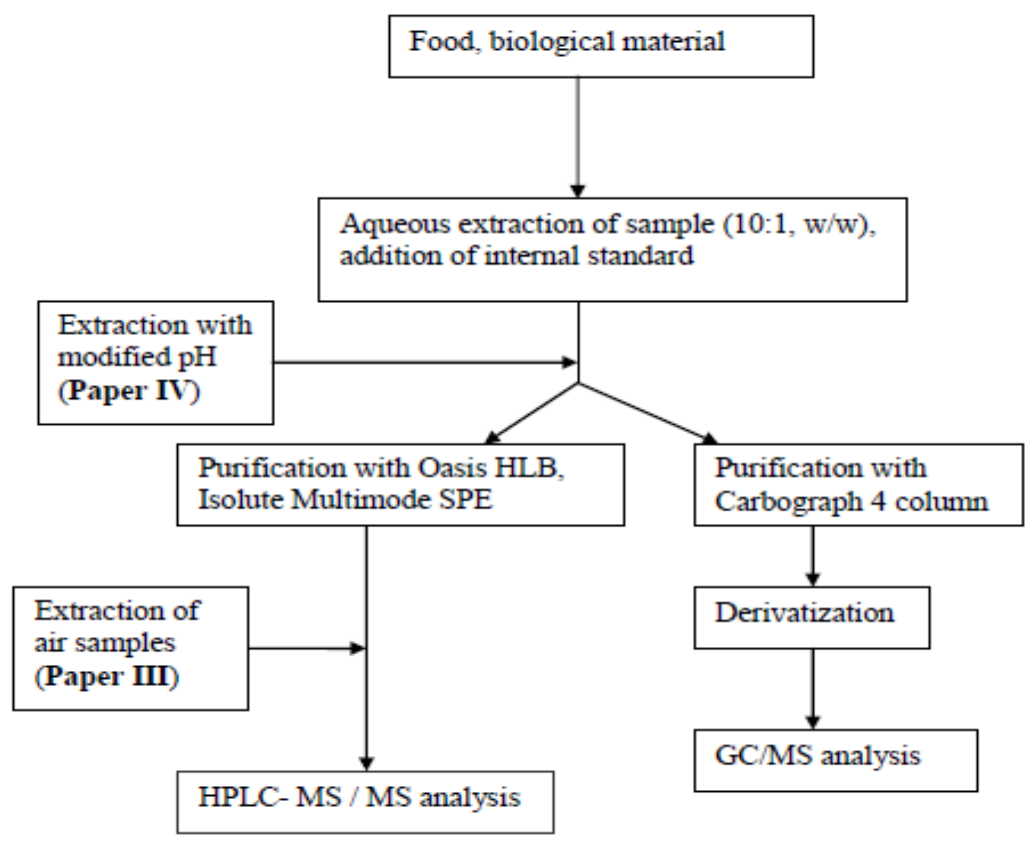

Figure 3. Summary LC-MS/MS-based method for measurement of acrylamide in food (Eriksson 2005)

Standard and conventional methods for the detection of AA in Foods Liquid Chromatography (LC) and high performance liquid chromatography (HPLC) coupled with mass spectrometry (MS) are the most preferred methods for separation and quantification of AA in foodsUltra-performance liquid chromatography (UPLC) allows better separation of AA in food matrices within a shorter retention time and higher sensitivity (Zhang et al., 2007). A UPLC-ESP (electrospray)-MS/MS method was reported for the detection of AA in foods, which supplied a rapid quantitative procedure for AA within a run time of only $3 \mathrm{~min}$, along with good repeatability (RSD
_ 4.5\%) within a day (n $1 / 4$ 5) and day-to-day (n $1 / 4$ 10) precision tests (Zhang et al., 2007).

Some papers developed and appliedGas chromatography coupled with electron capture detector (GC-ECD) successfully for the rapid determination of acrylamide in fried foods, such as potato crisps, potato chips, and fried chicken wings (Zhang et al., 2006). First GC-ECD method dealing with contaminant analysis of acrylamide and the first modified method employing potassium bromate and potassium bromide as derivatization reagents for acrylamide derivatization, the method included defatting with n-hexane, extraction with aqueous solution of sodium 
chloride $(\mathrm{NaCl})$, derivatization with potassium bromate $(\mathrm{KBrO} 3)$ and potassium bromide $(\mathrm{KBr})$, and liquid-liquid extraction with ethyl acetate. The final acrylamide extract was analyzed by GC-ECD for quantification and by GC-MS for confirmation. The chromatographic analysis was performed on the HPINNOWax capillary column, and good retention and peak response of acrylamide were achieved under the optimal conditions (numbers of theoretical plates $\mathrm{N}=83,815$ ).

The limit of detection (LOD) was estimated to be $0.1 \_\mathrm{g} \mathrm{kg}-1$ on the basis of the ECD technique. Recoveries of acrylamide from conventional samples spiked at levels of 150,500 and 1000 _g $\mathrm{kg}-1 \quad(\mathrm{n}=4$ for each level) ranged between 87 and $97 \%$ with relative standard deviations (RSD) of less than $4 \%$. Furthermore, the GCECD method showed that no cleanup steps of acrylamide derivative would be performed prior to injection and was slightly more sensitive than the MS/MS-based methods. Validation and quantification results demonstrated that this method should be regarded as a new, low-cost, and robust alternative for conventional investigation of acrylamide (Zhang et al., 2006).

Another simple, fast and costeffective method was developed by Altunay et al. (2016) for the indirect determination of acrylamide in processed foods particularly consumed by children. The method is based on ionpairing of acrylamide with fluorescein (F2_) in presence of $\mathrm{Ni}$ (II) ions at $\mathrm{pH} 9.0$, and then extraction of the formed ternary complex into a micellar phase of poly(ethyle- neglycol-mono-pnonylphenylether)

(PONPE7.5) before analysis by flame atomic absorption spectrometry (FAAS). In the near past, rapid and reliable liquid chromatography coupled to tandem mass spectrometry (LCMS/MS) method was developed Alpozena et al. (2015) for the determination of acrylamide in three different local bread types; wheat bread, bran bread, whole wheat bread. Acrylamide analyses were made in crust parts of the 85 bread samples. The method was linear up to $750 \mu \mathrm{g} \mathrm{kg}-1$ food with a determination coefficient of 0.999. Recovery rate was found 99.3\% with limit of detection and limit of quantification values of 1.5 $\mu \mathrm{g} \quad \mathrm{kg}-1$ and $5.0 \quad \mu \mathrm{g} \quad \mathrm{kg}-1$, respectively. Certified reference materials of crisp bread were analyzed and acrylamide contents of these samples were found in the range cited in the certificates. Statistical correlations were investigated between acrylamide contents and protein contents, reducing sugar contents, moisture contents, $\mathrm{pH}$, and color parameters $\left(L^{*}, a^{*}, b^{*}\right)$ of bread samples.

A recent method by Lambert et al. (2018) based on capillary 
electrophoresis (CE) is a powerful alternative for analyzing organic compounds based on charge-tomass differences with high separation efficiency. Two in-line preconcentration capillary zone electrophoresis (CZE) methods (field amplified sample injection (FASI) and stacking with sample matrix removal (LVSS)) have been evaluated for the analysis of AA in foodstuffs after being derivatized with 2-mercaptobenzoic acid, both of which showed similar sensitivity and precisions compared with chromatography-based methods (Bermudo, et al., 2006 and Bermudo et al., 2007). A laserinduced fluorescence detection method mediated by $\mathrm{CE}$ with $\mathrm{CdTe}$ quantum dots (QDs) as amplifier was studied for the detection of AA in potato crisps with good recoveries liquid chromatography coupled with tandem mass spectrometry to quantify acrylamide in foods. The AA content was determined by the reversed phasehigh performance liquid chromatography (RP-HPLC) method coupled to a diode array detector (DAD) (Michalak et al., 2017).

\section{Rapid detection methods}

Rapid detection methods are mainly based on biochemical properties of AA, biomaterials with high and specific interaction with $\mathrm{AA}$, or changes of physiochemical properties of thermally processed foods related to AA. The standard and rapid methods for detection of
AA in foods are summarized in Table 2

The method described by Asnaasharia et al. (2018) successes in determination of acrylamide even at low concentrations (figure 4). In their study, a simple, rapid and accurate fluorescent sensor was developed for detection of acrylamide based on gold nanoparticles (AuNPs) and FAMlabeled double-stranded DNA (FAM-dsDNA). The sensing method was developed in a way to produce a remarkable fluorescence intensity difference in the absence and presence of acrylamide. In the presence of acrylamide, the singlestranded DNA (ssDNA) and acrylamide adduct are formed. So that, FAM-labeled complementary strand DNA (FAM-csDNA) is free in the environment and adsorbed on the surface of AuNPs and as a result, the FAM is quenched by the AuNPs. Under optimized conditions, the presented fluorescent analytical approach showed high selectivity toward acrylamide with a wide linear response, $1 \times 10-7 \mathrm{M}-0.05 \mathrm{M}$, and a limit of detection (LOD) of $1 \times$ 10-8M for acrylamide.

Most recently method by Yadav et al. (2018) improved acrylamide biosensor was developed by immobilizing HbNPs onto paperbased devices. HbNPs based lab on chip acrylamide biosensor showed better analytic performance in terms of lower detection limit $(0.1 \mathrm{nM})$, wider working range $(0.1 \mathrm{nMe} 100$ 
$\mathrm{mM})$. The use of HbNPs not only improved the analytic performance of the biosensor but also simplified its fabrication process, transportable and economic.

Table 2. Applications of standard methods and rapid methods for detecting AA in thermally processed foods.

\begin{tabular}{|c|c|c|c|c|c|c|c|c|}
\hline & Method & Sample & linear range & $\begin{array}{l}\text { LOD } \\
\left(\mu \mathrm{g} \mathrm{kg}^{-1}\right)\end{array}$ & $\begin{array}{l}10 Q \\
\left(\mu g \mathrm{~kg}^{-1}\right)\end{array}$ & Recovery & RSD & Reference \\
\hline Standard & LC-MS/MS & Potato chips & $1-200$ & 1 & 3 & $81.6-99.0 \%$ & $0.4-4.5 \%$ & (Zhang et al,, 2007) \\
\hline \multirow[t]{9}{*}{ Methods } & (HPLC, UPLC) & Coffee & $2-100$ & 5 & 16 & $92-95 \%$ & $<5 \%$ & (Bortolomeazzi et al, 2012) \\
\hline & & $\begin{array}{l}\text { Cereal-based foods } \\
\text { (breakfast cereal, cookies) }\end{array}$ & $1-2,000$ & 6 & 18 & $90.6-98.5 \%$ & $\begin{array}{l}1.8 \% \\
\text { (mean) }\end{array}$ & (\$enyuva \& Cökmen, 2006) \\
\hline & & Tea & $1-20$ & 1 & 5 & $74-79 \%$ & $1.6-83 \%$ & (Liu, Zhao, Yuan, Chen, \& Hu, 2008) \\
\hline & & Infant foods & $0.1-200$ & 1 & 3 & $87-96 \%$ & $<6.5 \%$ & (Zhang et al, 2005) \\
\hline & GC-MS & Potato chips & $10-1,000$ & 5 & - & $81.9-95.7 \%$ & $53-13.4 \%$ & (Yamazaki et al.,2012) \\
\hline & (GC based) & Coffee & $0-1,500$ & 5 & 10 & $84-97 \%$ & $2-10 \%$ & $\begin{array}{l}\text { (Soares, Alves, Casal, Oliveira, \& } \\
\text { Fernandes, 2010) }\end{array}$ \\
\hline & & $\begin{array}{l}\text { Cereal-based foods } \\
\text { (biscuits, cracker, } \\
\text { breakfast cereals) }\end{array}$ & $5-50,000$ & 2 & 36 & $91-99 \%$ & $<4 \%$ & (De Vleeschouwer et al., 2007) \\
\hline & & French fries & $30-10,000$ & 1 & 25 & $>96 \%$ & $<2 \%$ & $\begin{array}{l}\text { (Notardonato, Avino, Centola, } \\
\text { Cinelli, \& Russo, 2013) }\end{array}$ \\
\hline & & Instant noodles & $10-5,000$ & 5.1 & 13 & $87.3 \%$ (mean) & $1.6 \%$ & (Yamazaki et al, 2012) \\
\hline \multirow[t]{13}{*}{$\begin{array}{l}\text { Rapid } \\
\text { Methods }\end{array}$} & $\begin{array}{l}\text { Electrochemical } \\
\text { Biosensors }\end{array}$ & Potato crisps & $\begin{array}{l}9.2 \times 10^{-4} \\
3.4 \times 10^{3}\end{array}$ & $8.5 \times 10^{-3}$ & - & - & - & (Stobiecka et al, 2007) \\
\hline & & Potato crisps & $0.35-5.3 \times 10^{6}$ & $1.4 \times 10^{-2}$ & - & $95.40-97.56 \%$ & - & (Batra, Lata, Sharma et al, 2013) \\
\hline & & No food detected & $0.71-710$ & 2.84 & 7.1 & - & - & (Garabagiu \& Mihallescu, 2011) \\
\hline & ELLSA & Pringles crisps & $51.76-3,311.5$ & 65.7 & - & - & - & (Preston et al,, 2008) \\
\hline & & Mashed potatoes & $50-1,280$ & 50 & 350 & $92.6-95.5 \%$ & - & (Fu et al.,2011) \\
\hline & & $\begin{array}{l}\text { Potato crisps, instant } \\
\text { noodles, biscuits, and cakes }\end{array}$ & $26,3-221.1$ & 18.6 & 60.6 & $74.4-98.1 \%$ & - & (Quan et al., 2011) \\
\hline & & Potato fries, biscuits & $10-100,000$ & 6 & - & $90-110 \%$ & $6.3-9.9 \%$ & (Zhou et al., 2008) \\
\hline & & $\begin{array}{l}\text { Potato chips, cookies, } \\
\text { and coffee }\end{array}$ & $0.25-24.15$ & 0,036 & - & $73.7-107.7 \%$ & $3.6-19.2 \%$ & (Wu et al., 2014) \\
\hline & Fluorescence & Potato chips & $35-350,000$ & 35 & - & - & - & (Hu et al, 2014) \\
\hline & & $\begin{array}{l}\text { French fries, fried puffs, } \\
\text { fried chicken roll, bread, } \\
\text { biscuits }\end{array}$ & $50-20,000$ & 15 & - & $66.0-110.6 \%$ & - & (Liuet al, 2014) \\
\hline & & & \multicolumn{2}{|c|}{ Correlation coefficient } & \multicolumn{2}{|c|}{ Prediction accuracy } & & Reference \\
\hline & Computer vision & Potato chips & \multicolumn{2}{|l|}{0.989} & \multicolumn{3}{|c|}{ 98\% at a threshold of $1000 \mu \mathrm{\mu g} / \mathrm{kg}$} & (Gökmen et al., 2006) \\
\hline & & Cookies & \multicolumn{2}{|l|}{0.946} & \multicolumn{3}{|c|}{$100 \%$ at a threshold of $150 \mu g / \mathrm{kg}$} & (Gökmen et al., 2008) \\
\hline
\end{tabular}




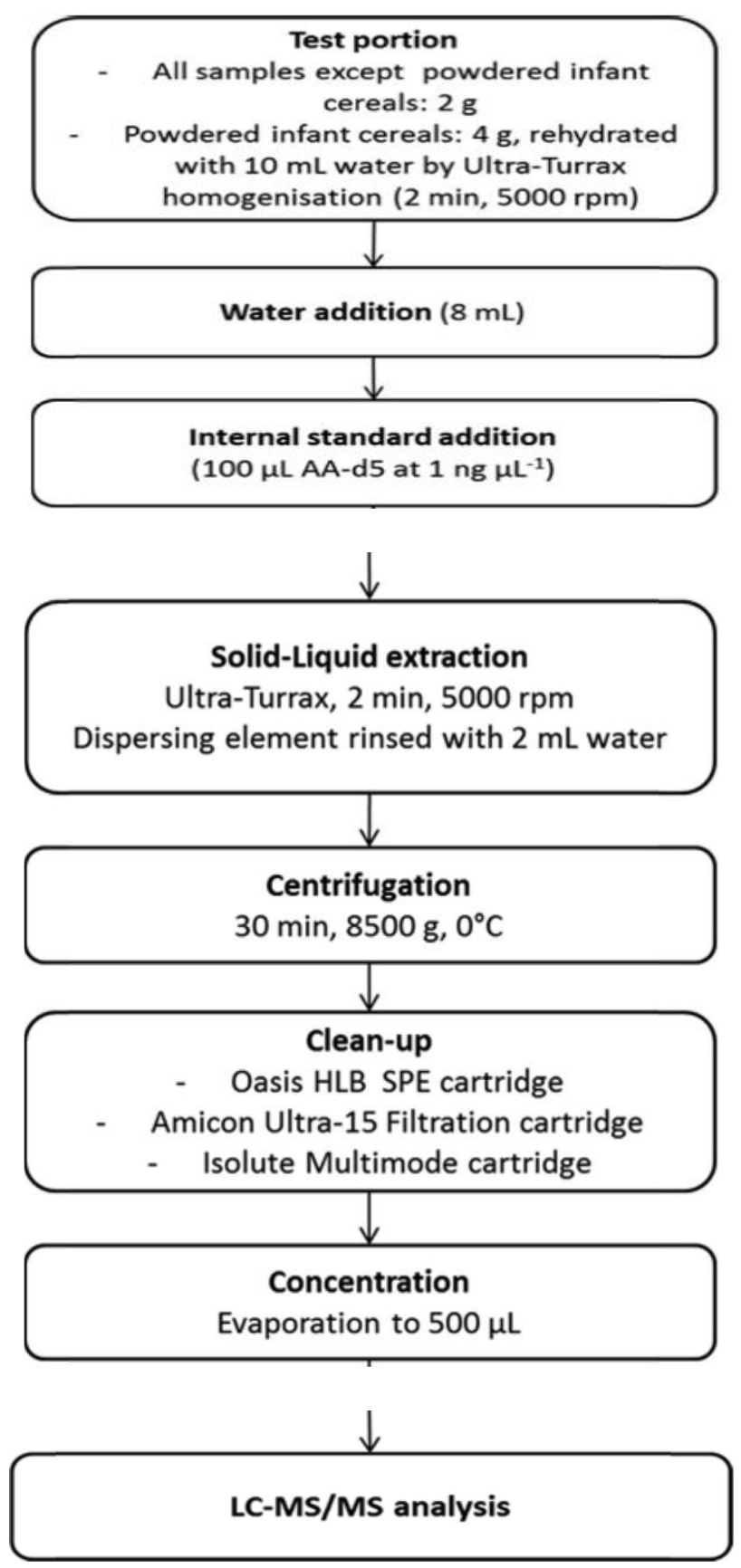

Fig. 4. Diagram of the sample extraction and purification proceduresaccording to method described by Asnaasharia et al .(2018) 


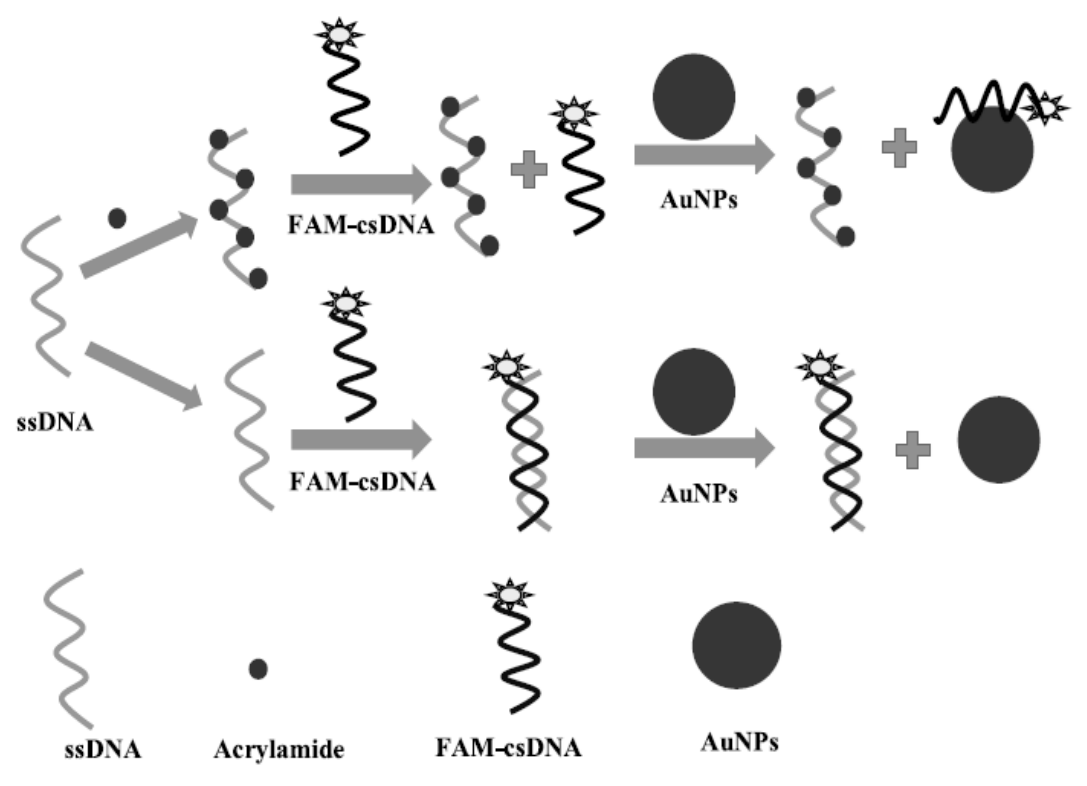

Scheme 1. Schematic description of acrylamide detection based on the fluorescent biosensor.

By Asnaasharia et al. (2018)

Table 3. analytical recovery of added acrylamide in processed foods measured by HbNPS/EPAD (Yadav et al., 2018).

\begin{tabular}{|lccc|}
\hline Sr.No. & $\begin{array}{r}\text { Acrylamide } \\
\text { added (mM) }\end{array}$ & $\begin{array}{r}\text { Acrylamide } \\
\text { found (mM) }\end{array}$ & $\begin{array}{c}\% \\
\text { Recovery }\end{array}$ \\
\hline 1 & - & 45.6 & 100 \\
2 & 15 & 59.8 & 98.67 \\
3 & 20 & 65.0 & 99.02 \\
\hline
\end{tabular}

\section{References}

Alpözen, E., Güven, G., Özdestan, Ö., \& Üren, A. (2015). Determination of acrylamide in three different bread types by an inhouse validated LC-MS/MS method. Acta Alimentaria, 44(2), 211-220.
Altunay, N., Gürkan, R., \& Orhan, U. (2016). A preconcentration method for indirect determination of acrylamide from chips, crackers and cereal-based baby foods using flame atomic absorption spectrometry. Talanta, 161, 143150. 
Asnaashari, M., Kenari, R. E., Farahmandfar, R., Taghdisi, S. M., \& Abnous, K. (2018). Fluorescence quenching biosensor for acrylamide detection in food products based on double-stranded DNA and gold nanoparticles. Sensors and Actuators B: Chemical, 265, 339345 .

Bermudo, E., Nú nez, O., Moyano, E., Puignou, L., \& Galceran, M. (2007). Field amplified sample injection ecapillary electrophoresisetandem mass spectrometry for the analysis of acrylamide in foodstuffs. Journal of Chromatography A, 1159(1), 225e232.

Bermudo, E., Nú nez, O., Puignou, L., \& Galceran, M. T. (2006). Analysis of acrylamide in food products by in-line preconcentration capillary zone electrophoresis. Journal of Chromatography A, 1129(1), 129e134.

Claus, A., Carle, R., \& Schieber, A. (2008). Acrylamide in cereal products: A review. Journal of Cereal science, 47(2), 118-133.

Delgado-Andrade, C., Morales, F. J., Seiquer, I., \& Navarro, M. P. (2010). Maillard reaction products profile and intake from Spanish typical dishes. Food research international, 43(5), 1304-1311.

Demirok, E., \& Kolsarıc1, N. (2014). Effect of green tea extract and microwave pre-cooking on the formation of acrylamide in fried chicken drumsticks and chicken wings. Food research international, 63, 290-298.EFSA, European Food
Safety Authority, 2016: Chemicals in Food, Overview of Selected Data Collection: Acrylamide in Food.

Eriksson, S. (2005). Acrylamide in food products: Identification, formation and analytical methodology (Doctoral dissertation, Institutionen för miljökemi).

FAO/WHO Consultation on Health Implications of Acrylamide in Food, World Health Organization. Food Safety Programme, World Health Organisation Staff, World Health Organization, FAO., WHO, \& Food Safety Programme. (2002). Health Implications of Acrylamide in Food: Report of a Joint FAO/WHO Consultation, WHO Headquarters, Geneva, Switzerland, 25-27 June 2002. World Health Organization.

Hu, Q., Xu, X., Fu, Y., \& Li, Y. (2015). Rapid methods for detecting acrylamide in thermally processed foods: A review. Food Control, 56, 135-146.

Kaplan, O., Kaya, G., Ozcan, C., Ince, M., \& Yaman, M. (2009). Acrylamide concentrations in grilled foodstuffs of Turkish kitchen by high performance liquid chromatography-mass spectrometry. Microchemical Journal, 93(2), 173-179.

Keramat, J., LeBail, A., Prost, C., \& Soltanizadeh, N. (2011). Acrylamide in foods: chemistry and analysis. A review. Food and bioprocess technology, 4(3), 340363.

Lambert, M., Inthavong, C., Hommet, F., Leblanc, J. C., Hulin, 
M., \& Guérin, T. (2018). Levels of acrylamide in foods included in 'the first French total diet study on infants and toddlers'. Food Chemistry, 240, 997-1004.

Michalak, J., Gujska, E., Czarnowska-Kujawska, M., \& Nowak, F. (2017). Effect of different home-cooking methods on acrylamide formation in preprepared croquettes. Journal of Food Composition and Analysis, 56, 134-139.

Ono, N. (2003). The nitro group in organic synthesis (Vol. 9). John Wiley \& Sons.

Oracz, J., Nebesny, E., \& Żyżelewicz, D. (2011). New trends in quantification of acrylamide in food products. Talanta, 86, 23-34.

Qin, L., Zhang, Y. Y., Xu, X. B., Wang, X. S., Liu, H. W., Zhou, D. Y., ... \& Thornton, M. (2017). Isotope dilution HPLC-MS/MS for simultaneous quantification of acrylamide and 5hydroxymethylfurfural (HMF) in thermally processed seafood. Food chemistry, 232, 633-638.

Rosén, J., \& Hellenäs, K. E. (2002). Analysis of acrylamide in cooked foods by liquid chromatography tandem

mass spectrometry. Analyst, 127(7), 880882.

Swedish National Food Administration, 24 April 2002. Information About Acrylamide in Food. Available: http://www.slv.se/engdefault.asp
Swiss Federal Office of Public Health (2002) Determination of acrylamide in food, [http://www.bag.admin.ch/verbrau/a ktuell/d/ AA_methode].

Takatsuki, S., Nemoto, S., Sasaki, K. \& Maitani, T. (2003). Determination of acrylamide in processed foods by LC/MS using column switching. Journal of the Food Hygienic Society of Japan, 44, 89-95.

Trevisan, A. J. B., de Almeida Lima, D., Sampaio, G. R., Soares, R. A. M., \& Bastos, D. H. M. (2016). Influence of home cooking conditions on Maillard reaction products in beef. Food Chemistry, 196, 161-169.

United States Food and Drug Administration (USFDA). (2004). Acrylamide in Foods. United States Food and Drug Administration, Washington, DC. Available from http://www.cfsan.fda.gov/ lrd/pest add.html\#acrylamide.

Yadav, N., Narang, J., Mishra, A., Chillar, A. K., \& Pundir, C. S. (2018). Paper-based electrochemical biosensor using haemoglobin nanoparticles for detection of acrylamide in processed foods. Journal of Food and Drug Analysis.

Yasuhara, A., Tanaka, Y., Hengel, M., \& Shibamoto, T. (2003). Gas chromatographic investigation of acrylamide formation in browning model systems. Journal of Agricultural and Food Chemistry, 51(14), 3999-4003. 
Zhang, Y., \& Zhang, Y. (2007). Zhang, Y., Dong, Y., Ren, Y., \& Formation and reduction of acrylamide in Maillard reaction: a review based on the current state of knowledge. Critical Reviews in Food Science and Nutrition, 47(5), 521-542.

Zhang, Y. (2006). Rapid determination of acrylamide contaminant in conventional fried foods by gas chromatography with electron capture detector. Journal of Chromatography A, 1116(1-2), 209216.

\section{تطور طرق الكشف عن الأكريلاميد في الأطعمة المطهية منذ اكتثافه لأول مرة عام

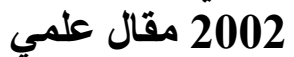 ندي حسين أحمد ، علي معوض أحمد ثقو إنجولف جريون}

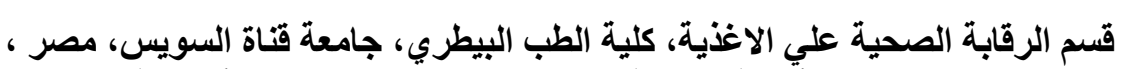

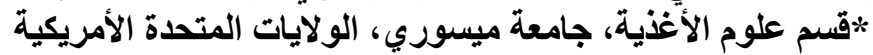

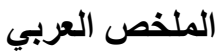

إن التغيير في اسلوب الحياة المعاصرة ادي الي ضرورة توفير وجبات جاهزة سريعة تو اكب سر عتها

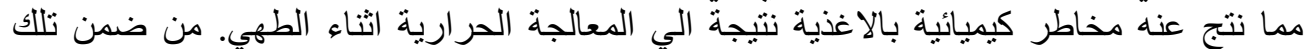

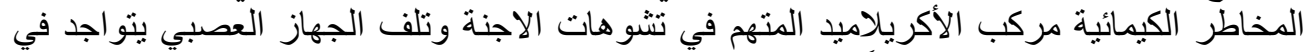

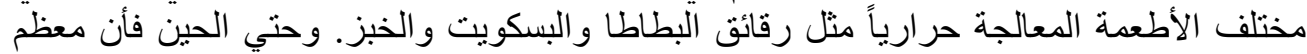

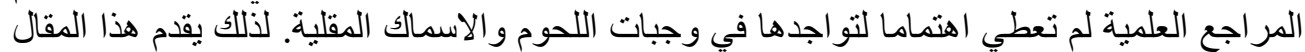

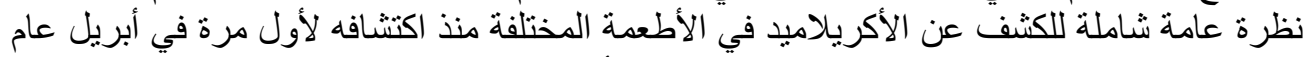

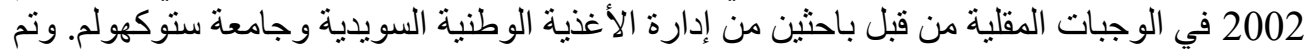

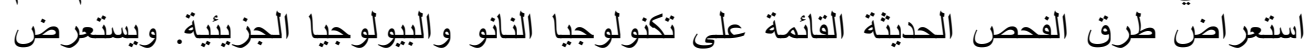

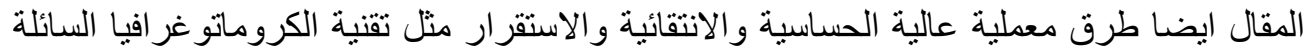

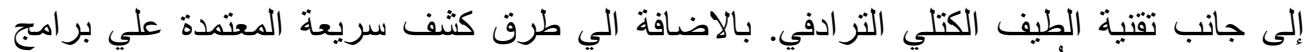

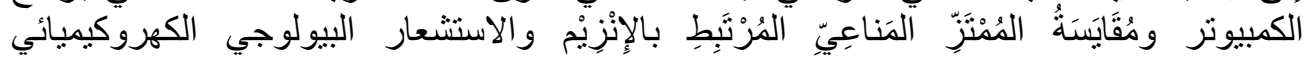

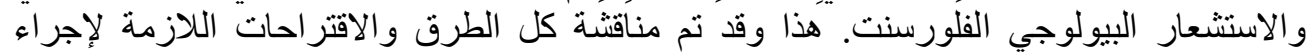

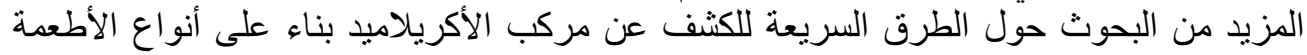
والتحديات التقنية. 